УДК 78. 038 (100) «20»

DOI 10.34064 / khnum 1-5502

\title{
Paliy Iryna
}

ORCID 0000-0002-9874-6825

\section{UNIONIQUE MUSIC AS A NEW PHENOMENON OF THE MUSICAL CULTURE: ANSWERING THE MAIN QUESTIONS}

\section{Annotation}

In this article we will talk about the interaction of music in fundamentally different areas - academic and non-academic, in which there is an interpenetration of musical language elements, expressive means from one sphere to another is happening, and a brand new quality musical material is produced. This new kind of music we call 'unionique music', and the aim of this article is to describe the unionique music phenomena, to base and explain its introduction into the musicology's use, and to define its place in the musical culture. Under the 'academic music' is understood the music of the West European classical tradition, under the 'non-academic' - such directions as jazz, rock, and folklore (ethnic). Using the method of functional analysis we examine musical compositions on three levels (composition, intonation and timbre). With the advance of internet technologies we now have an easy access to all kinds of different music that is composed in various styles and traditions. Convenience of communication made it possible for representatives of various nations to get acquainted with the musical languages of other ethnic groups and subsequently apply the elements of these languages to their creative work. This gave the ground for the emergence of a variety of musical directions in which interaction with different musical domains takes place. As a result, we now understand that the new paradigm of musical perception consists in the equality of all music types. Key words: unionique music, paradigm, domain, equality, academic and non-academic music.

Палий Ирина. 'Unionique music' как феномен музыкальной культуры: постановка проблемы. В статье изучается взаимодействие двух фундаментально различных сфер музыки - академической и неакадемической, 
при котором происходит взаимопроникновение элементов музыкального языка. Под академической музыкой понимаем западноевропейскую традицию музицирования, под неакадемической - джаз, рок и фолк (этническая музыка). Цель исследования - объяснить специфику как явления «unionique music», так и понятия, фиксирующего его новизну. На основе функционального подхода анализируются композиция, интонация, тембр отдельных примеров unionique music. В связи с распространением интернета возникла возможность неограниченного доступа к различным музыкально-стилевым направлениям. Удобство коммуникации позволяет представителям различных народностей ознакомиться с музыкальным языком других этнических групп и применять элементы «чужой» речи в своём творчестве. Это дало почву для появления новых стилевых направлений (где взаимодействуют различные музыкальные домены) и, как следствие, теоретическое обоснование unionique music в качестве новой парадигмы, ценность которой заключается в признании паритета всех сфер музицирования в условиях современной культуры. Ключевые слова: unionique music, nарадигма, домен, паритет, академическое и неакадемическое музицирование.

Палій Ірина. 'Unionique music' як феномен музичної культури: постановка проблеми. В статті досліджено взаємодію двох принципово різних сфер музикування - академічної та неакадемічної, де відбувається взаємодія елементів музичної мови. До академічної музики відносять західноєвропейську класичну традицію, до неакадемічною - джаз, рок та фолк (етнічна музика). Наслідком їхньої взаємодії стає принципово нова якість музичного матеріалу (як результату мислення), яку визначимо як unionique music. Метою $\epsilon$ обгрунтування явища unionique music та залучення поняття, що відбиває його зміст, до музикознавчого обігу. На грунті функціонального аналізу досліджено три рівні unionique music (інтонація, композиція, тембр). Завдяки новітнім засобам комунікації (зокрема, всесвітній інтернет-мережі) наявний доступ до величезної кількості ресурсів музики різноманітних стильових напрямків. Зручність комунікації дозволяє представникам різних етнічних груп знайомитися з музичною мовою інших народів та використовувати елементи «чужої» музичної мови в власній творчості. Це дало можливість теоретичного обгрунтування unionique music як нової парадигми музичної творчості, цінність якої полягає у паритеті всіх сфер музикування в умовах 
сучасної культури. Ключові слова: иnionique тиsic, парадигма, домен, паритет, академічне та неакадемічне музикування.

Background. The beginning of the 21 century is characterized by a complex crisis situation in culture, when the system of values is changing. On the one hand, they are based on the denial of the cultural and aesthetic experience of previous generations, which leads to the destruction of generally accepted, established methods. On the other hand, our time is connected with the tendency of strengthening globalization processes in the world and leveling the uniqueness of individual national cultures and traditions. The crisis of the 21 st century was preceded by the processes of changing the 'picture of the world' dramatically that lasted a century. The basis for the emergence of these processes was a series of events: numerous scientific discoveries completely changed people's perceptions of such categories as space, time, and speed. Thanks to the scientific progress, the opportunities for global communication were opened, which, in turn, caused mixing of cultures and their mutual enrichment.

The aim of this article is to describe the 'unionique music' phenomena, to base and explain its introduction into the musicology's use, and to define its place in the musical culture. Also in the article is revealed the essence of the new paradigm of musical thinking in the XXI century, which's main features are globalization and parity of the musical domains. The object is the music of the new domain (unionique music), which formed as a result of the musical evolution's ontogenetic process, and the subject - the compositions related to this domain.

In connection with the change of the 'picture of the world', a paradigm shift occurs. In 1962 Thomas Kuhn wrote the book 'The Structure of Scientific Revolutions' [6]. There he introduced the term 'paradigm'. For him a paradigm means universally recognized scientific achievements, which over a period of time give the scientific community a model of posing problems and solving them. Some common examples of actual research practice, including law, theory, their practical application and necessary equipment - all together give us models from which specific traditions of scientific research emerge. The gradual transition from 
one paradigm to another through the revolution is the usual pattern for the development of mature science. The formation of new means of communication and information is creating a new style of thinking, a new picture of the world and other principles of social organization. At the same time L. Kiyaschenko and V. Moiseev denote historical clearness of the paradigm [4]. A more precise historical definition is being specified, from the one hand, by delicate nature of following the example, which introduces the necessity for taking the bearers of paradigm knowledge into account (the features of a certain individual or community). And from the other it is determined by historically concrete action of the priorities among orders, which are forming the object matrix. Priorities in the scientific experience will be arranged differently depending on situation, in which this experience is. Thus, in the paradigm's period, exists a dynamic balance of the indicated principles, which are appropriate to 'normal music'. In preand post-paradigm situations, could dominate the principles, which initiate formation of the new rules of scientific activity [4, p. 196-197]).

While tracing the ontogenetic process of musical formation, we can find a definite regularity. Thus, all music could be divided into three main domains: 1 - ethnical, folk, 2 - Western European academic tradition, 3 jazz, rock and pop music. In the beginning, the domains were relatively pure, but with the approach of the XXI century, appeared a tendency to their interpenetration. The third domain is already a synthesis of the first two, and the fourth (concerning which we'll talk later) - a synthesis of the previous three. At that, until now music domains in musicological circles aren't considered equal. An axiological preponderance is evident in favor of Western-European academic tradition.

The conception of dividing music into three domains isn't absolutely new. It was described by V. Konen [5]. The author called these three domains 'layers'. But we don't agree with this definition because of its connection with the qualities, that 'layers' imply. The meaning of the word 'layer' itself denotes at clear-cut localization, separation, and also at the defined sequence. Thereby, layers' mixing and interaction is being perceived as something unnatural, or absurd, because its physical properties principally don't imply mixing. So, in our opinion, the 'domains' classification is more appropriate. 
It is also interesting to trace the history of the term 'third stream'. There is an opinion (Gunther Schuller), that the new direction of jazz (where jazz is tightly interacting with the Western European classical music) was denoted with this term. 'The lifting of external elements from one area into the other is happily the matter of the past. At its best Third Stream can be an extremely subtle music, defying the kind of easy categorization most people seem to need before they can make up their minds whether they should like something or not' [7, p. 116]. And after this Gunther Shuller is according to a conversation with John Lewis, who told: 'It isn't so much what we see (and hear) in the music of each idiom; it is more what we do not see in the one that already exist in the other' [7, p. 117]. In favor of this opinion witnesses the presence of Joe Zawinul's album 'The Rise and Fall of the Third Stream' (1968), which clearly demonstrates an interpenetration of language elements from these different music fields. There's no concerning to rock music, and as a result of confusion (simplification), not only jazz music was placed into the 'third stream' category, but also rock music, and even pop-music. To this misconception's spreading the works of V. Konen were promoting. In that way, the principle of motion 'from particular to general' had been (wrongly) applied.

Problems concerning genre and style classifications inside rock music, and the defining of rock and jazz music's place in the entire musical system are described by many authors (A. Moore, D. Brackett, Lori Burns and Serge Lacasse, K. Holm-Hudson, F. Holt, M. Stokes, R. Wastler). Thus, M. Stokes points: 'when concepts of culture are evoked to explain a musical genre, similar structural patterns are noted connecting music with other areas of cultural life. Structural homologies are juxtaposed, each explaining the other. Seen in these terms, Middleton, for example, notes the circular nature of these kinds of arguments, their lack of historicity, the assumption of a functional 'whole', a reified context from which music might be analytically abstracted (as if one could imagine, for example, some notion of 'African-American culture' without African-American music), their failure to problematize the complex nature of musical cognition (what it is, so to speak, that makes us hear music as music and not just a restatement of patterns reiterated elsewhere) and to assume a simple 'fit' between cultures, personalities and individuals' [9, p. 222-223]. 
As A. Shevchenko points [8], 'all ancient civilizations were formed in a period of transition - from the Stone Age to the Bronze Age, from primitive community to the first state formations. In relation to music this period corresponds to the transition from elementary intonation structures to the first mode pattern - pentatonic scale. Pentatonic is still the modal basis for numerous musical cultures of the Orient. As for ancient Greeks, they summarily overcame this stage in the musical progress of all people, adding dynamic structure to its development, which finally led to the foundation of European musical culture, which is basically different from the Oriental tradition' [8, p. 14]. The next stage of musical evolution is the ethnical musical language elements' (first domain) entering into academic Western European music (second domain). According to G. Schuller, 'the secular ballads of the troubadours became an essential structural element of the sacred motets of the fourteenth and fifteens century Ars Nova; and the folk and dance music of the last five centuries has at various times and in various ways profoundly affected the 'art music' of composers from Bach and Mozart to Bartók and Stravinsky' [7, p. 122]. Examples of composers' concern in ethnic and folk music, enriched with these new (and unusual) elements, increased to appear in the second half of the XIX century (such as Debussy, Dvořak, Brahms and Bartók). It's interesting that at the same time the birth of the third domain occurs - jazz music, which appeared as a result of the first and the second domains' music interference (ethnical African music and Western European academic music). Thus, in musicological circles appeared a question: to which category of social-esthetic system should jazz be placed? And by which attribute we should characterize its genre specificity: form, content features, method of performing? In our opinion, it is lawfully to consider music in its ontogenetic coming into being, which also determines the principles and thinking organization of its creators and performers. Inside the separate domains an evolution is proceeding as well; new genres are appearing, composers are adding their individual stylistic features to musical works of art. With an invention of electrical instruments, appeared such new musical styles, as rock and roll, rock and pop music. But nevertheless, the regularity is obvious: when there's a lack in expression means of one domain for the full potential release of artist's design, the necessary stepping outside its boundaries 
occurs, and new quality of music is forming. So, after about 100 years after the third domain's rise, the next domain is appearing - the unionique music, where musical elements of all systems are interacting on the levels of timbre, form and intonation. This term is a compound of the words 'union' and 'unique', the combination of which expresses the specificity of this domain's music most clearly. Thus, acoustic instruments sound along electric instruments, and so various principles of musical performing are combining. There could be a drum kit with regular rhythm at the same time with ethnical percussions and syncopated bass. Intonation system of quarter- and third-tone scales could exist alongside with tempered scales.

To give more precise picture of the unionique music, it is important to emphasize the following criteria:

1. Innovation, experimentation. Copies of innovative ideas rarely exceeding the originals. The unionique music specimens are often become as the single instances (their uniqueness), that could be metaphorically called 'The Red Book of Music' (with such compositions as Led Zeppelin's 'The Battle of Evermore', Pink Floyd's 'Atom Heart Mother', 'Being For The Benefit of Mr. Kite' by The Beatles, etc.) Usually, performers don't do the 'copies' of their unionique compositions. For example, there are just few of George Harrison's songs, inspired by the Indian ethnic music.

2. Nevertheless, on the base of the originally invented 'prototypes' and worked-out, perfected techniques the characteristic and recognizable performer's style could be formed (Yes, King Crimson, Frank Zappa, Oregon, etc.) Or mentioning how Pink Floyd's 'Echoes' flows into the latter 'The Dark Side of the Moon', creating their 'classic' sound. (The point, when the mine of the formed unique style is exhaust, is the matter of its creators' fantasy capacity).

3. The high level of performing, high standards of musical material's recreation on stage, often the increased complexity of compositions. From the performers it demands to master a wide spectrum of technical musical expressive means, and also the ability to 'switch' between three domains, which dictate their rules and principles of musical thinking and orientation.

4. Followers. If authors and performers don't deliver nothing new, but just use the characteristic techniques and approach (as it often occurs, you can literally hear the quotations, and the origin is being define 
automatically), such examples couldn't be classified as unionique. These performers might be called the continuators of the tradition, or the restorers. (Including quality cover bands, such as Australian Pink Floyd).

Appearance of the fourth domain is a natural stage of ontogenetic process of musical evolution. Each example of unionique music (a specimen or a formed style) is unique, and they could not be classified in terms of genre characteristics and categories. The common thing in such music is that compositions appear to be based on interaction of principally different domains. And from here comes the paradigm shift: the integrated, universal perception of music. Despite the fact that there are different principles of musical thinking organization and performing exist, in the XXI century the necessity to consider all music domains with equal attention became imminent. To percept musical domains selectively in modern environment of globalization, literally means to neglect (or negate) the progress; it is a step back into the ambiguity and interchangeability of genre definitions. It doesn't mean that we should stop studying separate musical domains in their pure form, but that we should take their purity as the determined stage of an ongoing ontogenetic process.

Unionique music is a widespread phenomenon today, and the scope of this article does not allow us to demonstrate a large number of examples of music of this specific kind. Nevertheless, one should pay special attention to several types of combinations. Now we'll get several examples that illustrate unionique music.

Kronos quartet with Franghiz Ali-Zadeh, composition 'Apsheron quintet 1' (2005). In this composition we are dealing with a mix of classical sound of a string quartet and Asian mugam. Here appears the level of intonation: non-tempered pitch as an imitation of Asian folk instruments. And the typical mugam-rhythm is perceived too.

The band Oregon. Composition 'Fond Libre' from the album 'Winter Lights' (1974). This example demonstrates an interaction of three musical domains: ethnic, classical and jazz. The music score contains jazz harmony and a 'double bass' jazz manner of playing, classical instruments, such as bass clarinet and oboe play an improvisation. At the same time sitar - a typical ethnic Indian instrument - plays a counterpoint in a jazz manner. 
Roy Harper. The title composition from album 'Sophisticated Beggar' (1967). This primarily folk song shows another way of domains' interaction. Ethnic Indian music is mixed here with blues. In the guitar part different elements of sitar-play-technique and blues elements sound at the same time. The vocal part sounds as an imitation of Indian vocal (fioritura ascending passage). So, there are two levels: timbre and intonation.

Trio Da Kali with Kronos Quartet. Composition 'Eh-Ya-Ye' from the album 'Ladilikan' (2017). This example demonstrates a mix of classical music with African ethnic music. We are dealing with the typical African vocal, polyphony of rhythm and thinking in short patterns, which is typical for African music. At the same time, the timbre of classical instruments (string quartet) brings classical elements into the overall sound.

Ravi Shankar. Concerto for sitar and orchestra. Part 4 Raga Manj Khamaj (1976). This example demonstrates an interaction of Western classical and Indian music. This is neither a true raga, nor a true concert form. However, the structure 'slow-fast-slow' and the system of leitmotivs are kept the same. Sitar plays with a classical intonation, but the Indian scales are applied too.

The band King Crimson. Composition 'Lizard' from the same titled album (1970). In this composition two domains of music, such as: classical, jazz and rock interact. From classical music we can find the rhythm of Bolero-dance, the timbre and intonation of a classical instrument - oboe. From jazz there are harmony, timbre of jazz instruments (saxophone, trumpet, and trombone) and improvisation. And from rock there are such elements as: the timbre of electric instruments (guitar, bassguitar) and rhythm parts.

Also Emil Viklicky project 'Sinfonietta - The Janacek of Jazz' (2009) could be mentioned as an interesting example. The famous Czech pianist, Viklicky gained international acknowledgment connecting modern jazz with elements of Moravian traditional songs' musical language.

Leoš Janáček (1854-1928) alongside with Bedřich Smetana (1824-1884) and Antonín Dvořák (1841-1904) is one of the three most famous Czech composers-classics. Creating his works, Janáček too had been including the Moravian folklore's expression means into them. (Jazz interpretation of Janáček's 'Sinfonietta', and also fragments from the opera 
'Jenůfa', Viklicky put into his album). Thus, we can trace the stages of musical ontogenesis: Janáček had been joining academic music with Czech folklore (I and II domains), and Viklicky is joining Janáček's music with jazz (all of the three domains), that allows us to put this musical material into the category of unionique music.

In conclusion, let's list some musicologists' opinions, which are strengthening our certainty for the 'paradigm shift' necessity.

For example, Robert Walser [10] developed 10 'apothegms' concerning the modern musicology's problems. The most significant of them (in the bounds of this article) are:

- The split between musicology and ethnomusicology is no longer useful, because it's constitutive dichotomies - self / other, Western / non Western, art / function, history / ethnography and text / practice - are no longer defensible.

- The split between musicology and music theory has never been useful because its constitutive dichotomy - culture / structure has never been defensible.

- 'Popular music' and 'classical music' cannot be compared in terms of value because these categories are interdependent and actively reproduced.

- You only have a problem of connecting music and society if you've separated them in the first place [10].

Another opinion relates to F. Holt, who pays a special attention to problems of musical genres' definitions, which exceed the bounds of the Western European academic music. 'If there are a lot of works concerning jazz and ethnic music (unfortunately, ethnomusicology still exists separately), for today there are just few works concerning genres' distribution and description inside rock music. The relation between folk and popular music, however, has frequently been one of opposition' [3, p. 30]. A classic example was declared by Middleton: 'the dichotomy between the notions of commercial popular music produced for 'the people' and authentic folk music created by 'the people' (Middleton, 2004). The two were also framed in exclusive terms when popular music studies started defining its field of inquiry in the late 1970s and scholars came up with general distinctions between folk, popular and art music. By that time musical and discursive components of folk and art music's 
had long circulated widely within popular music cultures and simulated the formation of styles such as folk-rock and art-rock. Today it no longer makes sense to view art, folk and pop music as separate cultural spheres or as a trichotomy into which all music can be organized. But the categories are still relevant for distinguishing between different forms of musical culture in more particular terms' [3, p. 30].

In that way, the appearance of the fourth musical domain - unionique music - is as well leading to the paradigm shift concerning musical perception. As a result, we now understand that the new paradigm of musical perception consists in the equality of all types of music.

\section{REFERENCES}

1. Burns, Lori, and Serge Lacasse, ed. 2018. The Pop Palimpsest: Intertextuality in Recorded Popular Music. Ann Arbor: University of Michigan Press.

2. Holm-Hudson, Kevin, ed. 2013. Progressive Rock Reconsidered. New York and London: Routledge.

3. Holt, Fabian. 2007. Genre in Popular Music. Chicago and London: University of Chicago Press.

4. Kiyashchenko L., Moiseev V. (2009) Philosophy of Transdisciplinarity, Moscow, 2009, 205 p. [in Russian].

5. Konen V. Dzh. (1994) Tretij plast: novye massovye zhanry v muzyke XX veka [The Third Layer - New popular genres in the 20-th Century Music], 1994, 160 s. [in Russian].

6. Kuhn, T. S. (1962) The Structure of Scientific Revolutions. Chicago: University of Chicago Press, 1962, 264 p.

7. Schuller G. (1986) Musings. The musical world of Gunther Schuller. New York: Oxford University Press. 315 p.

8. Shevchenko A. (2015) The music of Hellas. Kiev 'Publishing House Of Dmitry Burago', 2015. 248 p.

9. Stokes, Martin. Talk and text: popular music and ethnomusicology. Analyzing popular music 2003. Edited by Allan F. Moore, Publisher: Cambridge University Press, p. 318-339.

10. Walser, Robert. Popular music analysis: ten apothegms and four instances. Analyzing popular music 2003. Edited by Allan F. Moore, Publisher: Cambridge University Press, p. 16-38. 